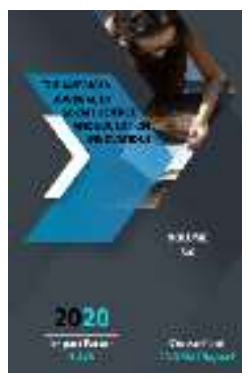

\title{
Fundamentals Of Lingvodidactics In Teaching Foreign Languages ( On The Example Of English Pedagogical Terms)
}

\author{
Kurbanova Munisa Akbaraliyevna \\ Researcher, Department Of Linguistics Uzbekistan State World Languages University, \\ Tashkent, Uzbekistan
}

Journal Website:

http://usajournalshub.c

om/index,php/tajssei

Copyright: Original

content from this work

may be used under the

terms of the creative

commons attributes

4.0 licence.

\section{ABSTRACT}

The purpose of the research is to improve the lingo didactic basis of teaching pedagogical terms in English and to illustrate ways to solve problems that arise in practice. use of interactive methods, analysis of the peculiarities of teaching pedagogical terms, study of the history of the origin of pedagogical terms and quantitative indicators in the assimilation layer, identification of the typology of problems in the practical application of pedagogical terms, the development of a system of utilization.

\section{KEYWORDS}

Didactic basis, terminology, pedagogy, linguodidactics, monolingualism, bilingualism, specialty, interactive method, situation-dialogue, situational-game, simulation, situation analysis, auction ideas, classification..

\section{INTRODUCTION}

As a result of the reforms carried out in our country, the education system has been radically reformed, the educational process has been adopted and put into practice in accordance with global educational standards and national values, as well as state educational standards aimed at integration of education. Tasks such as "training of modern personnel who know several foreign languages in our country, conducting research on foreign languages, improving the methodology of language teaching" are set. In this regard, due to the fact that today the world science is developing not within a single discipline, but in an interdisciplinary direction, in our country there are problems such as teaching foreign languages and language, their relationship to each other, the impact of these issues on society. Learning is important. In the 21st century, the development of 
foreign language skills of young people and the exchange of skills in the field of interstate pedagogy are important factors in the growing interest in English pedagogical terms. At the same time, there is a growing need to study sectoral terminology, its teaching in foreign languages, its comparative application in different languages, and trends in the development of specialist language. With the exception of terms that have been in use for years and have become ingrained in the vernacular, some terms have suddenly been adopted as new terms without being studied in depth in terms of content, and have been replaced by old ones. This creates a need for in-depth scientific and theoretical analysis and teaching of special pedagogical lexicon in English, Russian and Uzbek languages from the linguistic point of view, as there are words and terms that cover all areas in their field. It explains the need to teach terminology in foreign languages and fields, to study, understand, correctly translate pedagogical terms, to use and regulate them in practice, to enrich them at the expense of internal possibilities, to analyze archaisms and neologisms. Clarification of the linguodidactic basis of teaching pedagogical terms in English as a pedagogical field determines the relevance of this research.

These questions can be discussed in the research:

- What is the content and essence of the concept of linguodidactics?

- What is the importance of using interactive methods in teaching the vocabulary of pedagogical terms?

- What are the peculiarities of teaching pedagogical terms?

\section{BACKGROUND KNOWLEDGE}

The science of linguodidactics develops the general laws of the theory of language teaching, that is, it deals with the methodological basis of language teaching / learning. These include issues such as the goals, content, methods (principles), tools, methods of scientific research, and the relationship of language teaching with other disciplines. Teaching language aspects (vocabulary, grammar, pronunciation material) and types of speech activities (listening, speaking, reading, writing), as well as the organization of the learning process, etc. Jalolov says. [J.Jalolov, Samarkand, 2009]. Unlike math or other subjects, language classrooms use audio materials and visual aids as media. In this case, language plays two main roles at the same time: the subject of the lesson and the means of explaining the subject. In other words, the teacher of the Higher Education Institution must first use the language as a source of instruction or material (first role) (second role). As a result, the student learns English with the help of English. Of course, it is difficult to achieve such a success. Given that the first thing required of a teacher is field knowledge, his or her ability to use pedagogical terms in the classroom will help the student to master the lesson more easily.

It is appropriate to look at linguodidactics not as a set of pedagogical terms that serve to make the lesson boring and complicated, unnecessary and insignificant for the teacher and the student, but as a tool to increase lesson effectiveness and engage students in a deeper understanding of the methodological foundations of science. Indeed, Abdullah Avloni (1878 - 1934) put the problem of science at the forefront of all his research. "Fortunately," he wrote, "all our lives, our health, our happiness, our wealth, our life, our generosity, our zeal, our world and the hereafter are connected with science." Therefore, we must do our best to get rid of ignorance, which is the enemy of our body, 
without wasting time reading and knowing. [Abdulla Avloni, 1992].

Linguodidactics is a practical linguistic science that takes into account both the teaching of a foreign language and the acquisition of a foreign language. Linguodidactics studies the general laws of language teaching, develops methods and tools for teaching a particular language depending on the didactic objectives, the influence of monolingualism (monolingualism) or bilingualism (bilingualism) on language learning and solves a number of related problems.

So, let's talk about some of the comments on the science of foreign language teaching (lingvodidactics). Linguodidactics is derived from the Latin "lingua" "language" and the Greek "didacticos" "teaching" and is a science that deals with the creation of a general theory of language teaching. The term was first coined by the Russian linguist N.M. Shansky introduces that this science is designed to deal with the study of the problems of language teaching. The main tasks of lingvodidactics are to identify similarities and differences between languages, to analyze the content and structure of the studied language, to solve such problems as to establish the linguistic minimums necessary for the teaching process. The term lingvodidactics in general means the analysis of the study of theoretical and methodological problems of language teaching, taking into account the goals of language teaching [Djusupov, 2009, p. 27].

\section{METHODOLOGY}

\section{A. Research Design}

Communication is a process of teaching a foreign language for professional purposes, which means that professional linguodidactics consists of interethnic business and professional communication related to the theory of communication. Professional linguodidactics does not take place without reference to a special science, the expansion of knowledge about which takes place through the means of a foreign language. One of the most important problems of linguodidactics is the relevance of the study material to the phenomenon of the studied language, while the functional definition of terminology as an important system of the language of science (specialty) allows to approach the solution of this problem. A.M. According to Novikova, "the subject of study is a set of features, relationships and laws that are studied by this science and have a certain logical and definite form."...

\section{B. Participants}

In a short period of time, the interest of students in a foreign language can significantly increase and provide a lot of information, and the high demands on them are the conditions of the educational process of students' knowledge and skills. To meet this, new approaches to the organization of the educational process are needed. The expected result is a transition from a communicative to an interactive approach [Aysner, L.Yu. 2013. - p. 9-12.].

In today's rapidly evolving world, when teaching a foreign language, the teacher must first take into account the level of knowledge of the student. In order to study the importance of terms in the teaching of linguadidactics, observation and practical work was carried out with about 100 undergraduate students of the University of World Languages.

When a teacher teaches a foreign language, the student must have the ability to arouse interest in the language.

\section{Instruments}

On the use of interactive methods of teaching foreign languages in higher education. Blair [R.Blair, 2010], S. Martinelli [S.Martinelli, 
M.Tailor, 2000.], L. Konoplianyk [L.Konoplyanik, 2011. - p.p. 84-85], H. Stern [H.Stern, 1983.], E. Polat [E.S. Polat,, 2000.], M. Tailor [S. Martinelli, M. Tailor, 2000] and others have conducted scientific research. Interact means "cooperate", "act together", "carry on a dialogue". In other words, interactive methods focus not only on the interaction between teacher and students, but also on the interaction between students. The word "interactive" is synonymous with the word interactive and means "capable of acting on or influencing each other." [https: //www.synonyms].

Interactive learning is organized in such a way that almost all students are involved in the learning process. Student collaboration means that everyone contributes, sharing knowledge, ideas, and types of activities. As a type of interactive technology, multimedia is the full spectrum of information technology using a variety of software and tools that perform data processing in audio and visual mode to enhance the most effective impact on the user. Multimedia transmits audio, data and images over local, regional and global networks. Special programs for real-time communication allow the teacher to organize the team work of remote users with a program running on a local computer. Interactive work mode creates an integrated information environment of pictures, animation, photo, video, sound, text, where any student of any age can find completely new opportunities for lifelong learning. (see table 1) 

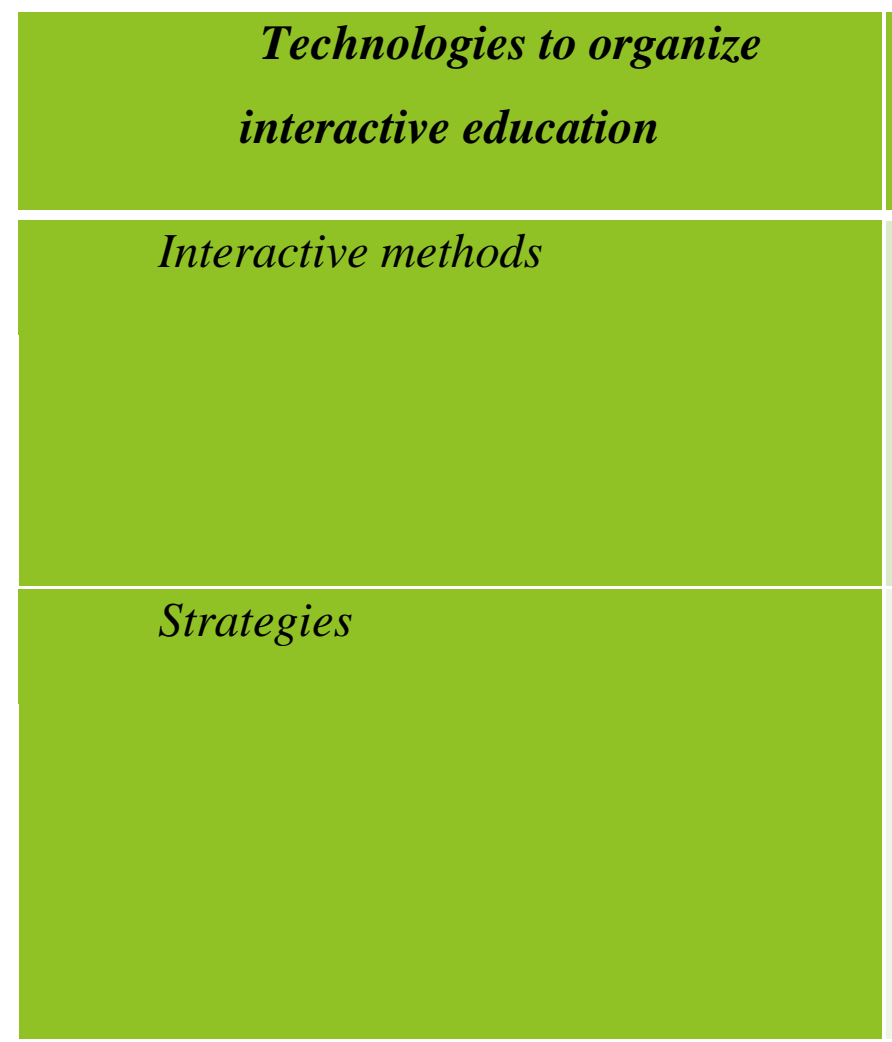

Graphic organizers

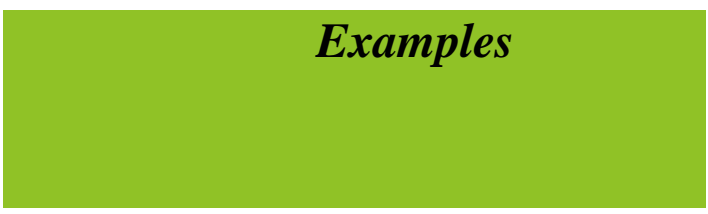

"Blitz-Survey",
"Modeling", "Creative Work",
"Relationship", "Plan",
"Conversation" and so on.

"Brainstorming",
"Boomerang", "Talerea", "Zig-
zag", "Stairs - stairs", "Museum",
"Rotation", "T-table", "Round
snow" and others.
"Fish Skeleton", "BBB",
"Conceptual Table”, "Veni
Diagram", "Insert”, "Cluster”,
"Why?", "How?" and others

\section{Table 1. Technologies to organize interactive education}

foreign language, not only the language itself (phonetics, grammar, vocabulary, structure) but also the history, customs, culture, great scholars and other important aspects of the country associated with that language. should also be taught.

Interactive learning technologies include clearly planned learning outcomes, interactive methods, tools and forms that stimulate the learning process, cognitive and mental conditions, and procedures for achieving planned outcomes [O.I. Pometun 2004]. Thus, interactive technologies encompass the 
Interactive methods that a teacher uses in their work.

Modern methodology defines the method as a way to achieve a goal. There are different perspectives in the classification of interactive teaching methods. For example, Panina and Vavilova used interactive methods in group discussions, games, and trainings [Generating Many Radical, Creative Ideas, p. 11]. Hollande initially classifies teaching methods according to the degree of involvement in the learning process and divides them into active and passive methods [O.I. Pometun 2004, p. 8]. Smith and Kochubey follow Holland to divide teaching methods into passive and interactive methods. Passive methods include reading, working with literature, and so on. Interactive technologies of foreign language teaching are based on an activity-based approach and include the use of interactive methods, including situation-dialogue and situationalgame, simulation, situation analysis, auction ideas, etc .; organic integration of different teaching aids (electronic and paper data), innovative processes in the educational process (distance learning) and traditional forms of education, the feasibility of their implementation and their interdependence replenishment principles [OI Pometun, 2004.].
The basis of interactive education is the direct communication of student-teacher, studentstudent, students-guest. It can be a single lesson, a series of lessons, or an entire course. Such a classification reflects the main features of interactive methods of teaching foreign languages: activity, collectivity and situational learning; developing students' reflection skills, attention, imagination, observation, innovative thinking; learning consistency, logical, critical thinking and creativity, efficiency, curiosity, cognitive independence and perseverance, achievement of goals.

\section{RESULTS}

Learning the pronunciation of pedagogical terms using interactive methods will strengthen the knowledge, understanding, practical application and analysis of these terms.

The specifics of pedagogical terms were determined by the forms of terminological nominations and areas of expression on the basis of pedagogical terms, group of scientific terms, linguistic features, naming of participants of pedagogical relations, grouping of English pedagogical terms by direct nomination and requirements of terminological vocabulary in pedagogical discourse (see table2). 


\begin{tabular}{|c|c|c|}
\hline № & Peculiarities & Pedagogical terms \\
\hline \multirow{4}{*}{1.} & \multirow{4}{*}{$\begin{array}{l}\quad \text { Spheres of } \\
\text { expression of } \\
\text { pedagogical } \\
\text { terms }\end{array}$} & 1) Pedagogical sciences \\
\hline & & 2) the field of education \\
\hline & & $\begin{array}{l}\text { 3) pedagogical discourse (school, institute, } \\
\text { university, the activities of teachers and the exchange of } \\
\text { methods between them). }\end{array}$ \\
\hline & & 1) educational journalism \\
\hline \multirow{3}{*}{2.} & \multirow{3}{*}{$\begin{array}{l}\text { Group of } \\
\text { scientific terms }\end{array}$} & $\begin{array}{l}\text { 2) general terms (for example, types of education, } \\
\text { places of teaching and learning, etc.) }\end{array}$ \\
\hline & & $\begin{array}{l}\text { 3) interdisciplinary terms (for example, school, } \\
\text { teacher, student, etc.) }\end{array}$ \\
\hline & & $\begin{array}{l}\text { 4) terms of the field (school, compulsory } \\
\text { education, education, teacher, student, school } \\
\text { obligations - general secondary school) }\end{array}$ \\
\hline \multirow[b]{2}{*}{3.} & \multirow{2}{*}{$\begin{array}{l}\text { Linguistic } \\
\text { features }\end{array}$} & $\begin{array}{l}\text { 1) Linguistic features of English pedagogical } \\
\text { terms, when taken separately }\end{array}$ \\
\hline & & $\begin{array}{l}\text { 2)Linguistic features that arise when a student } \\
\text { compares the English pedagogical term with the native } \\
\text { language pedagogical term }\end{array}$ \\
\hline 4. & Pedagogica & 1) terms that appear by adding new \\
\hline
\end{tabular}




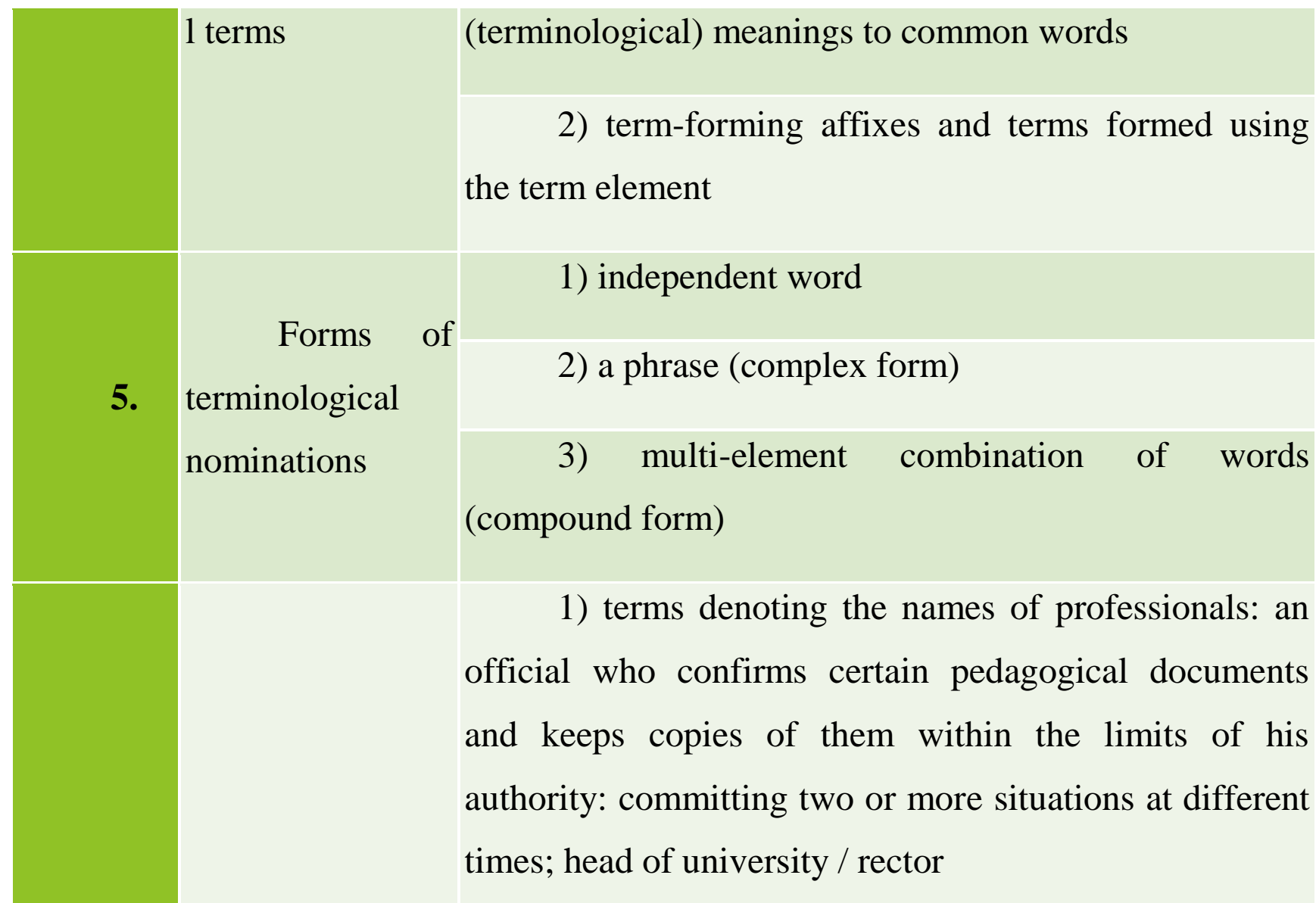

Terms

denoting the

6. naming participants in a pedagogical relationship of
2) Complaints related to the pedagogical process, responsible or involved as a third party, terms denoting the names of the subjects: petition; declaration of complains - the person who supervises at the beginning of the course process, during the course process: supervisor

3) Terms denoting the names of participants of pedagogical-legal relations: .... contest; right of the employer to change the working conditions without the consent of the worker 


\section{DISCUSSION}

Terminology is at the center of world linguistics today, along with a variety of other topics. One of the most difficult tasks today is to find "terminology" that has a broader meaning in modern linguistics and is being studied in greater depth. Terminology is the study of specific vocabulary, including the origin, form, meaning, function, and use of terms. Terminology is one of the most important areas of modern linguistic research. Nowadays, the growth of the problem of terminology is considered, on the one hand, due to the dynamic development of science and the proliferation of new concepts, on the other hand, due to insufficient study of issues such as the process of formation, development and function of terms. [KimV.N, 2009. C. 5.] Terminology is a very large part of the vocabulary of any language, and therefore terminology is evolving very rapidly because it allows the creation of new words. The terminology of a language consists of a system of many terms. A word or phrase in a particular field of knowledge, industry, or culture is called a term. The meaning of a word that a term refers to is interpreted by interpreting it in a relevant literature. The expression can be considered a linguistic term, wrote Z. Harris and I.F. Frisians. They are proponents of descriptive linguistics, who describe word expressions as follows: "A word expression is any human speech that can be expressed before or after silence." Each department or school of science develops specific terminology according to its nature and methods. Such specialized terminology is an important part of scientific research.

\section{CONCLUSION}

As a result of the above scientific research, we are based on the following conclusion:
1. Interactive technologies and interactive methods are based on the dialogue between the student and the teacher in the teaching of foreign languages, pedagogical terms, so the learning process involves all students in cognitive activity. It means the exchange of ideas, knowledge and experience. By participating in interactive activities, students learn to collaborate, think logically, analyze information, and solve problems. Prerequisites for effective language learning are free communication, expression of opinions and mutual respect. The use of interactive technologies is not the goal, but it should be seen as a means of creating the necessary conditions for communicatively effective teaching.

2. In short, the regulation of terminology is an important issue not only in the scientific field, but also in social life. The effectiveness of the regulation of terminology is evident in the following cases where the terms are directly used: in the correct organization of vocational education, in oral communication in industrial practice, in correspondence in scientific and production processes, in typography, in translating foreign literature. The specifics of pedagogical terms were determined by the forms of terminological nominations and areas of expression on the basis of pedagogical terms, group of scientific terms, linguistic features, naming of participants of pedagogical relations, grouping of English pedagogical terms by direct nomination and requirements of terminological vocabulary in pedagogical discourse. 


\section{REFERENCES}

1. Abdulla Avloniy. Òukiy guliston yoxud axloq. Ò., „O'qituvchi“, 1992

2. I.Karimov «Barkamol avlod orzusi». T.: o 'zbekiston milliy ensiklopediyasi, 2000. P86

3. J. Jalolov, Chet til o'qitish metodikasi „O' qituvchi“" Toshkent-2013.

4. Jalolov J.Jahon lingvodidaktikasining zamonaviy konseptual yangilanish bosqich xususida//Horijiy filologiya. №1 (30). - Samarqand, 2009. pp91-95.

5. Джусупов М. Лингводидактика и методика в полинаучной системе языкового образования. //Русский язык за рубежом, 2009, № 2, pp26-32

6. КимВ.Н., КимТ.С. Социальнополитическая терминология-Т., . 2009.

C.

7. Lingvodidaktika kak teoritecheskaya osnova obucheniya yazika. Elektronniy resurs:

http://works.doklad.ru/view/NRkF6riOleo. html. Data obrasheniya: 03.04.2019.

8. L.Konoplyanik, Interactive methods of teaching foreign languages in higher Education in: Materials of II International Scientific Conference "Modern trends in teaching a second language at schools and institutions of higher education ", Gorlovka, HDPIM, 2011. - p.p. 84-85.

9. H.Stern, Fundamental Concepts of Language Teaching, Oxford, Oxford University Press, 1983.

10. E.S. Polat, New pedagogical and information technology in education, Tutorial for students of pedagogical colleges, Moscow, Publishing center «Academy», 2000.

11. O.I. Pometun, Current lesson. Interactive learning technologies, scientific method, Kyiv, Publishing A.S.K., 2004.
12. R.Blair, Innovation approaches to language teaching, New York, Newbury House, 2010.

13. S.Martinelli, M.Tailor, Intercultural Learning, Strasbourg, Council of Europe and European Commission, 2000.

14. T.S. Panina, L.N. Vavilova, Modern methods of activization of training, Handbook for students, ed. by T.S. Panina, 4 th ed., Moscow, 2008. 